\title{
Surgical Results of Degenerative Spondylolisthesis Patients Over 70 Years O1d: A Single-Center Experience and Clinical Outcomes
}

\author{
70 Yaş Üstü Dejeneratif Spondilolistezisli Hastalarda Cerrabi Sonuçlar: \\ Tek Merkez Deneyimi ve Klinik Sonuçlar
}

Cem ATABEY ${ }^{1}$, Selcuk GOCMEN ${ }^{1}$, Hakan SIMSEK ${ }^{2}$, Emre ZORLU1 ${ }^{1}$, Mehmet Nusret DEMIRCAN ${ }^{1}$, $\mathrm{Ahmet}_{\mathrm{COLAK}}{ }^{1}, \mathrm{Cem} \mathrm{DINC}^{3}$

${ }^{1}$ GATA Haydarpasa Education Hospital, Department of Neurosurgery, Istanbul, Turkey

${ }^{2}$ Kasimpasa Military Hospital, Department of Neurosurgery, Istanbul, Turkey

${ }^{3}$ Memorial Hospital, Department of Neurosurgery, Istanbul, Turkey

Correspondence address: Selcuk GOCMEN / E-mail: s_gocmen@yahoo.com

\section{ABSTRACT}

AIM: The aim of this study is to evaluate results of surgery in Degenerative Spondylolisthesis (DS) patients over 70 years old.

MATERIAL and METHODS: This is a non-randomized retrospective analysis of the clinical outcome of 34 patients older than 70 years who underwent surgery. At the end of two-year follow-up period, preoperative and postoperative courses were assessed by Oswestry Disability Index (ODI) and Visual Analog Scales (VAS).

RESULTS: The mean age was 75 years (range 70-86 years). The mean duration of symptoms was 13.5 years (range 2-30 years). All patients underwent physiotherapy and also 15 ( 11 female, 4 male) patients used brace. L4-L5 was the most commonly affected level ( $n=26)$, Preoperative ODI and VAS scores were mean 71,63 (range 34-100) and 6,77 (range 2-9) ( $p<0,05)$. Postoperative ODI and VAS scores were mean 22,73 (range $0-100)$ and 2,13 (range $0-10)(p<0,05)$. Patients were asked if they had known the outcome, would they accept surgical treatment or not. 86.6\% $(n=26)$ of the patients answered the question positively.

CONCLUSION: A conventional decompressive laminectomy with foraminotomy and posterolateral fusion in situ with transpedicular instrumentation is necessary and reduces pain and recovers functional disability in elderly patients over 70 years old with DS.

KEYWORDS: Degenerative spine, Spondylolisthesis, Surgery, Transpedicular fixation

öz

AMAÇ: Bu çalışmanın amacı, 70 yaş üstü Dejeneratif Spondilolistezisli (DS) hastalarda cerrahinin sonuçlarını değerlendirmektir.

YÖNTEM ve GEREÇLER: Bu çalışma, 70 yaş üstü cerrahi yapılmış 34 hastanın klinik sonuçlarının non-randomize restrospektif analizidir. 2 yıllık takip sürelerinin sonunda, preoperatif ve postoperatif dönemler Oswestry Disability Index (ODI) ve Visual Analog Scales (VAS) skorları ile değerlendirildi.

BULGULAR: Ortalama yaş 75 yıldı (70-86 yaş arası). Semptomların ortalama süresi 13.5 yıldı (2-30 yıl arası). Tüm hastalar fizyoterapi görmüştü ve 15 hasta ( 11 bayan ve 4 erkek) korse kullanmıştı. L4-L5 en sık etkilenen seviyeydi ( $n=26)$, Preoperatif ODI ve VAS skorları ortalama 71,63 (34100 arası) ve 6,77 idi (2-9 arası) ( $p<0,05)$. Postoperatif ODI ve VAS skorları ortalama 22,73 (0-100 arası) ve 2,13 idi $(0-10$ arası) ( $<<0,05)$. Hastalara eğer sonucunu bilselerdi, ameliyatı kabul edip etmeyecekleri soruldu. Hastaların \%86.6'sı soruya olumlu cevap verdi.

SONUÇ: 70 yaş üstü DS'li yaşlı hastalarda, foraminotomi ile konvansiyonel dekompresif laminektomi ve in situ posterolateral füzyon ile transpediküler enstrümentasyon gerekir, ağrıları azaltır ve fonksiyonel iyileşme sağlar.

ANAHTAR SÖZCÜKLER: Dejeneratif omurga, Spondilolistezis, Cerrahi, Transpediküler fiksasyon

\section{INTRODUCTION}

Degenerative spondylolisthesis (DS) is a common disease in the elderly and L4-L5 is the most frequently affected level (4). Women and African-Americans are more commonly affected than men and whites. Diabetics are more vulnerable to DS (14). Spinal sagittal alignment and especially lumbar lordosis play a significant role in the development of DS. Patients mostly present with neurologic claudication, radiculopathy, intermittent low back pain and vesicorectal disorders (20). In the management of DS, non-surgical treatment is controversial (12)

The aim of the study is to determine whether surgical instrumentation improves the outcome or not and discuss the risks of morbidity and mortality due to surgical approach 
under the auspices of our clinical experiences in elderly patients over 70 years old.

\section{MATERIAL and METHODS}

This was a non-randomized retrospective analysis of the clinical outcome of 34 patients older than 70 years who were treated at the Gulhane Military Medical Academy (GMMA) Haydarpasa Training Hospital, Department of Neurosurgery between January 2007 and June 2009. Patients with lumbar DS of any grade presenting with low back pain or sciatica that caused severe functional restriction were included in the study.

All patients received conservative treatment before surgery for more than 2 years. Patients with previous spine surgery, alcohol/drug abuse, malignancy and infection were excluded from the study. Plain radiographs (anteroposterior, lateral and flexion-extension) and magnetic resonance imaging were used for evaluation. All patients were informed about complication rates, risks of operation, and chance of repeated physiotherapy before surgery. Patients underwent surgery comprising conventional decompressive laminectomy with foraminotomy and posterolateral in situ fusion with transpedicular instrumentation.

At the end of two-year follow-up period, preoperative and postoperative courses were assessed. Patients were asked by the physiotherapist who led postoperative exercise program to complete a questionnaire concerning their symptoms, functional disability and pain before and after the treatment. Their disability was quantified by Oswestry disability index (ODI) and Visual analog scales (VAS). All statistical analysis was performed with SPSS (Statistical Package for Social Sciences) for Windows 15.0 program. Wilcoxon Signed Ranks test was used.

\section{RESULTS}

A total of 34 (26 women and 8 men) patients underwent surgical treatment for DS. The mean age was 75 years (range 70-86 years). All female patients were housewives and male patients were retired civil servants. 24 patients had low back pain, 3 patients had sciatica, and 7 patients had both. The mean duration of symptoms was 13.5 years (range 2-30 years). All patients underwent physiotherapy and also 15 (11 female and 4 male) patients used brace as a conservative treatment (Table I). Conservative therapy relieved complaints temporarily and all patients had to undergo surgery due to repeated complaints. L4-L5 was the most commonly affected level $(n=26)$, L3-L4 was the second common level $(n=9)$ (Table II). $59 \%(n=20)$ of the patients had co-morbidities which included diabetes, hyperlipidemia, hypertension, thyroid disease (hyperthyroidism, hypothyroidism), chronic renal failure, chronic obstructive pulmonary disease, Parkinson disease, and prior of heart disease (heart failure, ischemic heart disease) (Table III). Hypertension and diabetes were the most commonly co-morbidities in preoperative periods. Intraoperatively, osteoporosis, hypertrophy of the facet joint with loss of joint fluid, mobility and rotation at the spondylolisthesic vertebrae were observed. Blood loss was $350 \mathrm{ml}$ (range 300-550 ml) and operation time averaged 150 minutes (mean 120-210 minutes). The mean hospital stay was 4 days. Postoperative course was uneventful and there were not any pedicle screw migrations. None of the patients needed a revision surgery. Two patients had dural tear requiring primary repair and fibrin glue application during the operation. No implant fractures, wound infections occurred. All were followed-up for at least two years.

Patients presenting leg pain experienced dramatic improvement in their complaints immediately after the operation. All patients had to bear with pain at the operation site. The preoperative ODI and VAS scores significantly improved at the $2^{\text {nd }}$ year follow-up assessment except eight patients. Four patients continued to have leg pain at followup. Two of female and two of male patients died in the first year of follow-up due to cardiologic problems. Preoperative ODI and VAS scores were mean 71,63 (range 34-100) and 6,77 (range 2-9) $(p<0,05)$. Postoperative ODI and VAS scores were mean 22,73 (range 0-100) and 2,13 (range 0-10) $(p<0,05)$ (Table IV).

Patients were asked if they had known the outcome, would they accept surgical treatment or not. $86.6 \%(n=26)$ of the patients answered the question positively. $13.6 \%(n=4)$ of the patients were regretful for undergoing surgical treatment. They had residual pain after surgery and we could not find out the reason. But, that might be attributed to distraction of the spondylolisthesic level after instrumentation.

\section{DISCUSSION}

Lumbar degenerative spondylolisthesis is quite common in elderly patients. Although most patients respond to conservative treatment, surgery is indicated when it becomes insufficient to control symptoms (21). A positive effect of surgery could be demonstrated according to the data of preoperative conservative treatment of patients in the current study and the outcome was better with fusion surgery than conservative treatment. Functional outcome and pain resolution of patients were statistically significant compared to their status before surgery, strongly suggesting that the outcome of surgery is not solely the result of decompression but also the result of the fusion with transpedicular instrumentation. The previous studies showed satisfactory clinical outcomes from fusion in spondylolisthesis with an average outcome rate of $77 \%$ (18). There was only one controlled study comparing surgical treatment with conservative treatment if there was a placebo effect of surgery. Turner et al suggested that placebo effects influence patient outcomes after any treatment; including surgery that the clinician and patient believe was effective (12). The current nonrandomized study with a 2-year follow-up rate of $88,23 \%$ shows the use of pedicular screws in managing elderly DS patients over 70 years old. The clinical outcome did not correlate with results from randomized trials by Fischgrund et al, who specifically studied DS, and results reported by Thomsen et al, who studied a mixed group of patients $(7,17)$. 
Table I: Summary of the Study Group Data

\begin{tabular}{|c|c|c|c|c|c|c|c|c|c|}
\hline patient & age & $\operatorname{sex}$ & complaint & $\begin{array}{c}\text { duration of } \\
\text { complaint (year) }\end{array}$ & level & brace & physiotherapy & $\begin{array}{l}\text { blood } \\
\text { loss (ml) }\end{array}$ & $\begin{array}{l}\text { surgery time } \\
\text { (min) }\end{array}$ \\
\hline 1 & 74 & $\mathrm{~F}$ & $\mathrm{LwB}+\mathrm{Lg}$ & 2 & L4-5 & & + & 320 & 150 \\
\hline 2 & 76 & $\mathrm{~F}$ & LwB & 20 & $L 2-3 / 3-4 / 4-5$ & + & + & 410 & 200 \\
\hline 3 & 70 & $\mathrm{~F}$ & LwB & 4 & L4-5 & & + & 350 & 180 \\
\hline 4 & 72 & $\mathrm{~F}$ & $\mathrm{LwB}+\mathrm{Lg}$ & 2 & L3-4 & & + & 420 & 200 \\
\hline 5 & 70 & $\mathrm{~F}$ & LwB & 8 & L4-5 & & + & 350 & 180 \\
\hline 6 & 78 & $\mathrm{~F}$ & LwB & 20 & L4-5 & & + & 310 & 120 \\
\hline 7 & 74 & $\mathrm{~F}$ & LwB & 15 & L4-5 & + & + & 330 & 120 \\
\hline 8 & 72 & $\mathrm{~F}$ & LwB & 4 & L4-5 & & + & 340 & 150 \\
\hline 9 & 85 & $\mathrm{~F}$ & LwB & 15 & L5-S1 & & + & 420 & 200 \\
\hline 10 & 71 & $\mathrm{~F}$ & LwB & 10 & L2-3 / 3-4 / 4-5 & & + & 300 & 120 \\
\hline 11 & 72 & $\mathrm{~F}$ & LwB & 30 & L3-4/4-5 & + & + & 550 & 210 \\
\hline 12 & 79 & $\mathrm{~F}$ & $\mathrm{LwB}+\mathrm{Lg}$ & 2 & L4-5 & & + & 350 & 120 \\
\hline 13 & 71 & $\mathrm{~F}$ & LwB & 10 & $L 2-3 / 3-4$ & & + & 330 & 120 \\
\hline 14 & 73 & $\mathrm{~F}$ & $\mathrm{LwB}+\mathrm{Lg}$ & 4 & L4-5 & + & + & 300 & 140 \\
\hline 15 & 71 & $\mathrm{~F}$ & $\mathrm{LwB}+\mathrm{Lg}$ & 30 & L4-5 & & + & 310 & 120 \\
\hline 16 & 74 & $\mathrm{~F}$ & LwB & 10 & L5-S1 & + & + & 380 & 150 \\
\hline 17 & 71 & $\mathrm{~F}$ & LwB & 15 & L4-5 & & + & 380 & 160 \\
\hline 18 & 70 & $\mathrm{~F}$ & LwB & 25 & L3-4 /4-5 & + & + & 390 & 180 \\
\hline 19 & 71 & $\mathrm{~F}$ & LwB & 30 & L4-5 & & + & 300 & 120 \\
\hline 20 & 71 & $\mathrm{~F}$ & $\mathrm{Lg}$ & 2 & L4-5 & & + & 320 & 130 \\
\hline 21 & 80 & $\mathrm{~F}$ & $\mathrm{LwB}+\mathrm{Lg}$ & 2 & $\mathrm{~L} 2-3 / 3-4 / 4-5$ & + & + & 420 & 190 \\
\hline 22 & 70 & $\mathrm{~F}$ & LwB & 30 & L4-5 & & + & 310 & 120 \\
\hline 23 & 74 & $\mathrm{~F}$ & LwB & 30 & L3-4 / 4-5 & + & + & 380 & 160 \\
\hline 24 & 78 & $\mathrm{~F}$ & LwB & 2 & L1-2 & + & + & 320 & 120 \\
\hline 25 & 70 & $\mathrm{~F}$ & LwB & 30 & L3-4 / 4-5 & + & + & 340 & 130 \\
\hline 26 & 81 & $\mathrm{~F}$ & $\mathrm{LwB}+\mathrm{Lg}$ & 20 & L4-5 & + & + & 370 & 150 \\
\hline 27 & 86 & M & LwB & 8 & L4-5 & + & + & 370 & 140 \\
\hline 28 & 77 & $M$ & $\mathrm{LwB}+\mathrm{Lg}$ & 2 & $\mathrm{~L} 2-3$ & & + & 300 & 180 \\
\hline 29 & 75 & $M$ & LwB & 15 & L5-S1 & & + & 310 & 130 \\
\hline 30 & 80 & M & LwB & 20 & $\mathrm{~L} 2-3$ & + & + & 320 & 150 \\
\hline 31 & 82 & $M$ & LwB & 30 & L4-5 & & + & 320 & 140 \\
\hline 32 & 81 & M & LwB & 2 & L4-5 & + & + & 310 & 150 \\
\hline 33 & 71 & $M$ & LwB & 10 & L4-5 & + & + & 330 & 120 \\
\hline 34 & 83 & $M$ & $\operatorname{Lg}$ & 2 & L4-5 & & + & 340 & 150 \\
\hline
\end{tabular}

F: female; M: male; LwB: low back pain; Lg: leg pain; L: lumbar; ml: milliliter; min: minute.

Table II: Distribution of Patients' Spondylolisthesis Levels According to Sex

\begin{tabular}{|c|c|c|c|c|c|}
\hline sex / levels & L1-2 & L2-3 & L3-4 & L4-5 & L5-S1 \\
\hline$F(n: 26)$ & 1 & 4 & 9 & 21 & 2 \\
\hline M (n: 8) & & 2 & & 5 & 1 \\
\hline
\end{tabular}

F: female; M: male; $\boldsymbol{n}$ : number; L: lumbar; S: sacral. 
Table III: Summary of the Co-morbidities. 4 Patients Died in the First Year of Follow-up Due to Cardiologic Problems

\begin{tabular}{|c|c|c|c|c|c|c|c|c|c|}
\hline $\begin{array}{c}\text { Patients } \\
(n=20)\end{array}$ & Diabetes & Hypertension & Hyperlipidemia & $\begin{array}{l}\text { Thyroid } \\
\text { disease }\end{array}$ & $\begin{array}{l}\text { Chronic } \\
\text { renal } \\
\text { failure }\end{array}$ & $\begin{array}{l}\text { Chronic } \\
\text { obstructive } \\
\text { pulmonary } \\
\text { disease }\end{array}$ & $\begin{array}{c}\text { Parkinson } \\
\text { disease }\end{array}$ & $\begin{array}{c}\text { Prior of } \\
\text { heart } \\
\text { disease }\end{array}$ & $\begin{array}{l}\text { Postoperative } \\
\text { Outcomes }\end{array}$ \\
\hline 1. & & Yes & & & & & & Yes & Exitus \\
\hline 3. & & Yes & & & & & & & Good \\
\hline 4. & Yes & & & & & & & & Good \\
\hline 8. & Yes & Yes & & & & & & & Good \\
\hline 9. & & Yes & & Yes & & Yes & & & Good \\
\hline 10. & Yes & Yes & & & & & & Yes & Good \\
\hline 11. & & Yes & & Yes & & & & & Good \\
\hline 14. & Yes & Yes & & & & & & & Good \\
\hline 16. & & Yes & & & & & & & Good \\
\hline 17. & & Yes & & Yes & & & Yes & & Good \\
\hline 18. & Yes & Yes & & & & & & & Good \\
\hline 20. & Yes & Yes & & & & & & & Exitus \\
\hline 21. & & Yes & & & Yes & & & & Good \\
\hline 25. & & Yes & Yes & & & Yes & & & Good \\
\hline 26. & & Yes & & & & & & Yes & Good \\
\hline 27. & Yes & Yes & & & & & & Yes & Exitus \\
\hline 28. & & & & & & Yes & & & Good \\
\hline 29. & Yes & Yes & & & Yes & & & & Good \\
\hline 31. & & Yes & & & & & & & Good \\
\hline 32. & & Yes & Yes & & & & & & Exitus \\
\hline
\end{tabular}

Table IV: Mean Values of Disability Rating Index and Pain Index Before Treatment and at 2-Year Follow-Up Assessments for the Study Group. SPSS (Statistical Package for Social Sciences) for Windows 15.0

\begin{tabular}{|c|c|c|c|}
\hline All patients & $\begin{array}{c}\text { Mean } \\
\text { preoperative scores }(\mathbf{n = 3 4 )}\end{array}$ & $\begin{array}{c}\text { Mean } \\
\text { postoperative 24 } \\
\text { scores (total } \mathbf{3 0} \text { *) }\end{array}$ & $\begin{array}{c}\text { Ponth } \\
\text { (Wilcoxon Signed Ranks) }\end{array}$ \\
\hline ODI & 71,63 & 22,73 & $P<0,05$ \\
VAS & 6,77 & 2,13 & $P<0,05$ \\
\hline
\end{tabular}

(*) Four patients died due to cardiologic problems at the postoperative first year.

n: number; preop: preoperative; postop: postoperative; ODI: Oswestry disability index; VAS: visual analog scale.

Clinical outcome shows a good improvement in the back pain and sciatica.

At the follow-up evaluation, the outcomes of the patients after operation were better than the outcomes of the same patients before operation who underwent conservative treatment for 2 years. The differences between outcomes were significant for pain, functional disability and overall outcome. All patients were over 70 years old and not working (without objective outcome data), and there was therefore only subjective data (pain, VAS and ODI) which show a better result with surgery than with conservative treatment. The difference between preoperative and postoperative values of VAS and ODI was statistically significant in the current study.

In contrast to our study, many retrospective studies have reported good results in adults who had conservative treatment for spondylolisthesis $(3,10,12,15,16)$, . However, the conservative treatment in our study did not produce similar results as the literature. The patients underwent conservative treatment over and over again. The physiotherapy and brace relieved complaints temporarily. In our opinion, the treatment of DS may not be possible with conservative treatment due to osteoporosis and facet joint instability.

The placebo effect of treatment modalities is well known (19). However, the best results of conservative treatment have been reported in patients with acute onset of pain in the literature. Stenier and Micheli reported good results with brace treatment in their patients (16). In addition to that, Blanda et al reported brace treatment was not successful 
for the spondylolisthesis (3). In the current study, we could not claim an optimal physiotherapy was performed but all patients used a brace at least for 2 months.

O'Sullivan reported that the patients with spondylolisthesis who underwent specially designed exercise training had good outcome (13). We could not standardize the physiotherapy. Hometowns of the patients were different cities and they underwent physiotherapy in different state hospitals. However, in the presented study, all patients underwent physiotherapy more than two years. After a silence period without pain and disability, their complaints recurred.

Surgery is a treatment modality of DS $(7,20)$. Transpedicular fixation with or without fusion, decompressive surgery without fusion and etc. are various surgical techniques found in the literature $(1,2,8,11)$. Some suggested good results (17) and some emphasized ineffective results and complications of surgery $(5,6,8)$. In the presented study, the fact is that conservative treatment did not change the fate and all elderly patients over 70 years old underwent surgery.

Both preoperative and postoperative VAS used for quantification of pain and preoperative ODI has been shown to have the functional disability. VAS reflects relative rather than absolute disability. Patients were asked whether they would accept surgical treatment or not if they had known the outcome. In the current study, all patients compared their preoperative and postoperative pain scores. A few patients had residual pain after surgery. latrogenic neurological symptoms after spinal cord or spinal roots involvement, misguided screws, stress fractures and loosening of screws are the most dangerous reasons $(5,6,9)$. In the current study, we could not find out any clue about the reason. But, that might be attributed to distraction of the spondylolisthesic level after instrumentation. So, reduction forces must be calculated carefully before the operation. Importance of experience in spondylolisthesis surgery is emphasized one more time.

\section{CONCLUSION}

Although the conservative treatment is one of the chosen methods for therapy, patients inevitably undergo surgery after sometime. Consequently, conventional decompressive laminectomy with foraminotomy and posterolateral fusion in situ with transpedicular instrumentation is necessary and reduces pain and recovers functional disability in elderly patients over 70 years old with DS.

\section{REFERENCES}

1. Anonymous: Diagnosis and Treatment of Degenerative Lumbar Spondylolisthesis, in Clinical Guidelines for Multidisciplinary Spine Care. Burr Ridge, IL: North American Spine Society, 2008

2. Audat ZM, Darwish FT, Al Barbarawi MM, Obaidat MM, Haddad WH, Bashaireh KM, Al-Aboosy IA: Surgical management of low grade isthmic spondylolisthesis; a randomized controlled study of the surgical fixation with and without reduction. Scoliosis 6: 14, 2011
3. Blanda J, Bethem D, Moats W, Lew M: Defects of pars interarticularis in athletes: A protocol for nonoperative treatment. J Spinal Disord 5:406-411, 1993

4. Cauchoix J, Benoist $M$, Chassaing V: Degenerative spondylolisthesis, its cause and effect. Clin Orthop Relat Res 115:122-129, 1976

5. Deyo RA, Mirza SK, Martin BI, Kreuter W, Goodman DC, Jarvik JG: Trends, major medical complications and charges associated with surgery for lumbar spinal stenosis in older adults. JAMA 303:1259-1265, 2010

6. Fehlings MG, Rabin D: Surgical complications in adult spondylolisthesis. J Neurosurg Spine 13:587-588, 2010

7. Fischgrund JS, Mackay $M$, Herkowitz HN, Brower $R$, Montgomery DM, Kurtz LT: Degenerative lumbar spondylolisthesis with spinal stenosis: A prospective randomized study comparing decompression laminectomy and arthrodesis with and without spinal instrumentation. Spine 22:2807-2812, 1997

8. Giudici F, Minoia L, Archetti M, Corriero AS, Zagra A: Longterm results of the direct repair of spondylolisthesis. Eur Spine J 20:115-120, 2011

9. Godlewski P, Twaróg Z, Mazurkiewicz T: Complications of transpedicular spine fixation and their causes. Ortop Traumatol Rehabil 6:222-226, 2004

10. Gramse RR, Sinaki M, Ilstrup D: Lumbar spondylolisthesis: A rational approach to conservative treatment. Mayo Clin Proc 55:681-686, 1980

11. Kleinstueck FS, Fekete TF, Mannion AF, Grob D, Porchet F, Mutter $U$, Jeszenszky $D$ : To fuse or not to fuse in lumbar degenerative spondylolisthesis: Do baseline symptoms help provide the answer? Eur Spine J 21(2):268-275, 2012

12. Möller $H$, Hedlund R: Surgery versus Conservative management in adult isthmic spondylolisthesis. A prospective randomized study: Part I. Spine 25:1716-1721, 2000

13. $\mathrm{O}^{\prime}$ Sullivan PB, Twomey LT, Allison GT: Evaluation of specific stabilizing exercise in the treatment of chronic low back pain with radiologic diagnosis of spondylolysis or spondylolisthesis. Spine 22:2959-2967, 1997

14. Rosenberg NJ: Degenerative spondylolisthesis: Predisposing factors. J Bone Joint Surg Am 57:467-474, 1975

15. Sinaki M, Lutness MP, Ilstrup DM, Chu CP, Gramse R: Lumbar spondylolisthesis: Retrospective comparison and three-year follow-up of two conservative treatment programs. Arch Phys Med Rehabil 70:594-598, 1989

16. Steiner ME, Micheli LJ: Treatment of symptomatic spondylolysis and spondylolisthesis with modified Boston brace. Spine 10:937-943, 1985

17. Thomsen K, Cristensen FB, Eiskjaer SP, Hansen ES, Fruensgaard $S$, Bünger CE: The effect of pedicle screw instrumentation on functional outcome and fusion rates in posterolateral fusion: A prospective randomized clinical study. Spine 22:2813-2822, 1997

18. Turner JA, Ersek M, Herron L, Haselkorn J, Kent D, Ciol MA, Deyo R: Patient outcomes after lumbar spinal fusions. JAMA 268(7):907-911, 1992 
19. Turner JA, Deyo RA, Loeser JD, Von Korff M, Fordyce WE: The importance of placebo effects in pain treatment and research. JAMA 271:1609-1614, 1994

20. Vibert BT, Sliva CD, Herkowitz HN: Treatment of instability and spondylolisthesis: Surgical versus non-surgical treatment. Clin Orthop Relat Res 443:222-227, 2006
21. Xu H, Tang H, Li Z: Surgical treatment of adult degenerative Spondylolisthesis by instrumented transforaminal lumbar interbody fusion in the Han nationality. J Neurosurg Spine 10: 496-499, 2009 